\title{
The Influence of No-Till, Conventional Tillage and Nitrogen Fertilization on Physico-Chemical and Biological Indicators After Three Years of Monoculture Barley
}

\author{
Vincenzo Tabaglio ${ }^{* 1}$, Carolina Gavazzi ${ }^{1}$, Cristina Menta ${ }^{2}$ \\ ${ }^{1}$ Istituto di Agronomia Generale e Coltivazioni Erbacee, Università Cattolica del Sacro Cuore \\ Via Emilia Parmense 84, 29100 Piacenza, Italy \\ ${ }^{2}$ Dipartimento di Biologia Evolutiva e Funzionale, Università di Parma \\ Via Farini 90, 41100 Parma, Italy
}

Received: 21 July 2008. Accepted: 10 October 2008.

\begin{abstract}
An experimental trial was carried out over three years at Cavacurta (Po valley, Italy) on continuous barley. The soil was a coarse-loamy over sandy, mixed, mesic Fluventic Ustochrept. The experimental design was a split-plot with four replicates; the main factor was the soil management system (conventional tillage, CT, and no-tillage, NT), while the secondary factor was the nitrogen fertilization $\left(\mathrm{N}_{0}=0, \mathrm{~N}_{1}=50\right.$ and $\mathrm{N}_{2}=90 \mathrm{~kg} \mathrm{~N}^{-1}$ year $\left.^{-1}\right)$. At the end of the third year soil samples were taken in all plots at four depths $(0-5,5-10,10-15$ and $15-20 \mathrm{~cm})$. For these samples, $\mathrm{pH}$, organic matter, total $\mathrm{N}$, available $\mathrm{P}$ and cation exchange capacity were determined. On the contrary, water aggregate stability was determined for a single layer $\left(0-20 \mathrm{~cm}\right.$ depth), excluding the $\mathrm{N}_{1}$ level of fertilization. The biological indicator, QBS-ar index, was studied only in the layer $0-10 \mathrm{~cm}$. Statistical analysis shows that no-till positively influenced all the indices except for CEC and QBS-ar. $\mathrm{N}$ fertilization had significant effects on CEC only; in the upper layer, the value in $\mathrm{N}_{2}$ subplots was of approx. $1 \mathrm{cmol}^{+} \mathrm{kg}^{-1}$ higher than in $\mathrm{N}_{0}$ and $\mathrm{N}_{1}$ subplots. There was no significant interaction for any of the indices. As regards only the $0-20 \mathrm{~cm}$ layer, the most important results are as follows. The organic matter content in NT plots was significantly higher than in CT plots (32.6 vs $\left.29.8 \mathrm{~g} \mathrm{~kg}^{-1}\right)$, as was the total $\mathrm{N}$ ( $\left.2.11 \mathrm{vs} 1.97 \mathrm{~g} \mathrm{~kg}^{-1}\right)$. No-till also had a very clear effect on the Olsen-P (12.3 vs $\left.9.3 \mathrm{mg} \mathrm{kg}^{-1}\right)$. The most remarkable result was found for the water aggregate stability: for NT plots the value was $246 \%$ higher than for CT plots (34.3 vs 9.9\%). As regards the microarthropod community, the value of the QBS-ar index was between 90 and 126 , a typical range for soil under barley.
\end{abstract}

Key-words: soil indicators, no-tillage, conventional tillage, nitrogen fertilization, QBS-ar, water aggregate stability.

\section{Introduction}

Since the early 1960s, the technique of no-tillage (NT) has come up against various obstacles in Italy. Initially, experimental studies were sporadic, but more recently NT has been studied repeatedly. However, NT has never been applied over a large area (Toderi and Bonari, 1986; Bartolini, 1989; Caliandro et al., 1992; Sartori and Peruzzi, 1994). The limited use of this land management technique is due to several factors: limited acceptance by farmers of the new principles, wrong choice of soil-type, short experimental studies without sufficiently long repeti- tions, and inadequate basic knowledge of the various herbicide treatments and fertilizers needed. As regards $\mathrm{N}$ fertilization especially, rates and times of application of fertilizer need to be modified to suit the new soil regime. Mineralisation and nitrogen release are lower under NT and the residue decomposition temporarily causes some limitation of available nitrogen as the micro-organisms draw on soil reserves to satisfy their own nutritional needs (Wild, 1988). With the adoption of high residue systems, additional evaluation of the $\mathrm{N}$ efficiency is needed, in relation to weather conditions, soil prop-

\footnotetext{
* Corresponding Author: Fax: +39 0523 599222. E-mail address: vincenzo.tabaglio@unicatt.it
} 
erties, rotation and crop characteristics. Barley has low nitrogen requirements, usually less than $100 \mathrm{~kg} \mathrm{~N} \mathrm{ha}^{-1}$, so the rate of nitrogen application must be carefully calculated to avoid decreasing the yield or $\mathrm{NO}_{3}-\mathrm{N}$ leaching and $\mathrm{N}_{2} \mathrm{O}-\mathrm{N}$ emission (Angas et al., 2006; Halvorson and Reule, 2007; Malhi and Lemke, 2007).

Nevertheless, the advantages and conditions for the adoption of NT have been repeatedly presented and discussed worldwide (Phillips and Phillips, 1984; Sprague and Triplett, 1986; Baker and Saxton, 2006; Pisante, 2007; Triplett and Dick, 2008). NT is generally one of the most sustainable soil management systems in that it reduces runoff and soil erosion, increases available plant water, increases soil organic matter and available plant nutrients, reduces labour requirements and machinery costs, reduces fossilfuel inputs, reduces greenhouse gas emission from agricultural land, and improves the global environment (Unger and McCalla, 1980; Rajendra Prasad and Power, 1991; Reicosky and Saxton, 2007). More specifically, in the absence of the plough the soil profile is undisturbed and the environment is less oxidative, the most important consequence being an improvement in soil quality and health over time (Adl et al., 2006). The most appropriate techniques for detecting and measuring this improvement need to be identified. Given that a single parameter cannot describe the complexity of the soil ecosystem, it becomes necessary to establish how many and which soil quality indicators to use (Larson and Pierce, 1991; Doran and Parkin, 1994). For this study, chemical ( $\mathrm{pH}$, organic matter, total nitrogen, available phosphorus, cation exchange capacity), physical (water aggregate stability) and biological (QBS-ar) indicators were considered, thus adopting an integrated approach for assessing soil quality. As regards the biological community, mesofauna groups are a key component of soil biota. They are very abundant, their role in soil formation and transformation is well-recognized and the area covered during their life cycle is representative of the site under examination. Their life cycle gives insight into the ecological condition of the soil, and several species have already been recognised as useful biological indicators of soil quality. In general, soil invertebrate-based indices consider the consistency and richness of populations (van Straalen, 1998). Recently the integrated QBS-ar index has been proposed (Parisi, 2001; Parisi et al., 2005).

The aim of this field experiment was to verify the ability of these indicators to detect any changes in soil quality in relation to the shift in tillage management and different levels of nitrogen fertilization, after three years of continuous barley.

\section{Materials and methods}

An experimental trial was carried out over three years (2000-2002) at Cavacurta (Lodi, Northern Italy), on continuous barley. The soil was a coarse-loamy over sandy, mixed, mesic Fluventic Ustochrept (Soil Taxonomy, 1992), previously under mixed sward for two years. The main physical and chemical properties of the soil at the beginning of the experiment are shown in Table 1 . The experimental design was a splitplot with four replicates; the main factor was the soil management system (conventional tillage, CT, and no-tillage, NT), while the secondary factor was the rate of applied nitrogen $\left(\mathrm{N}_{0}=0, \mathrm{~N}_{1}\right.$ $=50$ and $\mathrm{N}_{2}=90 \mathrm{~kg} \mathrm{~N}^{-1}$ year $\left.^{-1}\right)$. Nitrogen was applied as ammonium nitrate twice at the end of tillering and at the beginning of stem elon-

Table 1. Physical and chemical properties of the soil at the beginning of the experiment.

\begin{tabular}{llr}
\hline Sand $(2-0.05 \mathrm{~mm})$ & $\mathrm{g} \mathrm{kg}^{-1}$ & 302 \\
Silt $(0.05-0.002 \mathrm{~mm})$ & $\mathrm{g} \mathrm{kg}^{-1}$ & 505 \\
$\mathrm{Clay}(<0.002 \mathrm{~mm})$ & $\mathrm{g} \mathrm{kg}^{-1}$ & 193 \\
$\mathrm{pH}(\mathrm{CaCl}, 0.01 \mathrm{M})$ & & 7.23 \\
$\mathrm{CaCO}_{3}($ volumetric) & $\mathrm{g} \mathrm{kg}^{-1}$ & 90 \\
Organic matter (Walkley and Black) & $\mathrm{g} \mathrm{kg}^{-1}$ & 27.9 \\
Total N (Kjeldahl) & $\mathrm{g} \mathrm{kg} \mathrm{k}^{-1}$ & 1.97 \\
Available P (Na bicarbonate 0.5 M, pH 8.5) & $\mathrm{mg} \mathrm{kg}^{-1}$ & 11.8 \\
Exchangeable K (Ba chloride, pH 8.1) & $\mathrm{mg} \mathrm{kg}^{-1}$ & 81.0 \\
C.E.C. (Ba chloride, pH 8.1) & $\mathrm{cmol}^{+} \mathrm{kg}^{-1}$ & 20.2 \\
\hline
\end{tabular}


Table 2. Soil $\mathrm{pH}$ after three years of continuous barley under two soil tillage systems and three rates of nitrogen fertilization.

\begin{tabular}{lccccc}
\hline & \multicolumn{5}{c}{ Layer } \\
\cline { 2 - 6 } & $0-5 \mathrm{~cm}$ & $5-10 \mathrm{~cm}$ & $10-15 \mathrm{~cm}$ & $15-20 \mathrm{~cm}$ & $0-20 \mathrm{~cm}$ \\
\hline Tillage system & 0.01 & 0.01 & 0.05 & 0.05 & 0.01 \\
$\mathrm{NT}$ & $7.33 \mathrm{a}$ & $7.38 \mathrm{a}$ & $7.37 \mathrm{a}$ & $7.37 \mathrm{a}$ & $7.36 \mathrm{a}$ \\
$\mathrm{CT}$ & $7.55 \mathrm{~b}$ & $7.53 \mathrm{~b}$ & $7.52 \mathrm{~b}$ & $7.50 \mathrm{~b}$ & $7.53 \mathrm{~b}$ \\
$\mathrm{~N}$ fertilization & n.s. & n.s. & n.s. & n.s. & n.s. \\
$\mathrm{N}_{0}$ & 7.45 & 7.50 & 7.47 & 7.44 & 7.41 \\
$\mathrm{~N}_{1}$ & 7.41 & 7.42 & 7.43 & 7.46 & 7.45 \\
$\mathrm{~N}_{2}$ & 7.46 & 7.45 & 7.44 & n.s. & n.s. \\
Interaction & n.s. & n.s. & 7.4 .44 & 7.45 \\
Average & 7.44 & 7.46 & 7.45 & 7.44 \\
\hline
\end{tabular}

n.s., not significant at the $\mathrm{P} \leq 0.05$ level; 0.05 , and 0.01 , significantly different at $\mathrm{P} \leq 0.05$ and $\mathrm{P} \leq 0.01$ levels, respectively; within the same column, means followed by the same letter are not significantly different at the $\mathrm{P} \leq 0.05$ level, according to the LSD test. $\mathrm{NT}=$ no-tillage; $\mathrm{CT}=$ conventional tillage; $\mathrm{N}_{0}=0 \mathrm{~kg} \mathrm{~N} \mathrm{ha}^{-1} ; \mathrm{N}_{1}=50 \mathrm{~kg} \mathrm{~N} \mathrm{ha}^{-1} ; \mathrm{N}_{2}=90 \mathrm{~kg} \mathrm{~N} \mathrm{ha}^{-1}$.

gation. The 24 subplots were $3.6 \mathrm{~m}$ wide and 12 $\mathrm{m}$ long. The CT plots were ploughed each year to a depth of $30 \mathrm{~cm}$, and then harrowed twice to a depth of $15 \mathrm{~cm}$ using a rotating harrow to provide a suitable seedbed. In the NT plots the residues of the previous crop were chopped and then Glyphosate was sprayed at the rate of 3 $\mathrm{L} \mathrm{ha}^{-1}$ to kill standing weeds at sowing. The notill drill used was the John Deere 750. At the end of the three-year period, soil samples in all plots at four depths (0-5, 5-10, 10-15 and 15-20 $\mathrm{cm})$ were taken. Each sample was made up of 3-4 subsamples. For these samples, $\mathrm{pH}(0.01 \mathrm{M}$ $\mathrm{CaCl}_{2}$ ), organic matter (Walkley and Black, 1934), total N (Kjeldahl, 1883, modif. for Büchi Distillation Unit K-350), available P (Olsen and Sommers, 1982) and cation exchange capacity $\left(\mathrm{BaCl}_{2}\right)$ were determined. On the contrary, water aggregate stability (Malquori and Cecconi, 1962 modif.) was determined only for 16 plots for a single layer $(0-20 \mathrm{~cm})$, excluding the $\mathrm{N}_{1}$ level of fertilization. The original method was modified for a single time determination (60') and with correction for sand according to Kemper (1965). The microarthropod community was studied on an undisturbed soil sample set taken from the top $10 \mathrm{~cm}$, by means of the QBSar index. The QBS-ar index is applied to soil microarthropods, separated according to the "biological form" approach, with the intention of evaluating their level of adaptation to the soil environment and overcoming the well-known difficulties of taxonomic analysis to species level for edaphic mesofauna. This index evaluates the level of morphological adaptation to the soil environment shown by microarthropod groups and, on this basis, assigns a numerical value of soil biological quality. Microarthropods were extracted by means of a Berlese-Tullgren funnel. Analysis of variance was used for statistical analysis of all data; the LSDs were calculated for $\mathrm{P} \leq 0.05$ level.

\section{Results and discussion}

At the end of the three-year trial, the soil $\mathrm{pH}$ (Tab. 2) was found to be slightly alkaline: 7.45 on overall average for the $0-20 \mathrm{~cm}$ layer compared to 7.2 determined at the start of the experiment (Tab. 1). This difference is primarily due to different depths of sampling $(30 \mathrm{~cm}$ at the start and $20 \mathrm{~cm}$ at the end of the trial). Nevertheless, all the values are optimal for microbial activity. Compared with CT, NT shows significantly lower values at all depths, at different probability levels. The decrease is very slight, being between 0.22 for the $0-5 \mathrm{~cm}$ layer and 0.17 for the $0-20 \mathrm{~cm}$ layer. After only three years of NT, the soil macroporosity had probably increased due to the development of a system of biochannels, so that drainage was improved and calcium leaching slightly more intensive than in $\mathrm{CT}$, where the plots are ploughed annually. The nitrogen fertilization had no significant effect on soil $\mathrm{pH}$ or the interaction between the experimental factors. According to Landi et al. (2000), the soil organic matter (Tab. 3) is the most reactive soil component. Under NT, the organic matter reached the value of $43.6 \mathrm{~g} \mathrm{~kg}^{-1}$ in the 
Table 3. Soil organic matter $\left(\mathrm{g} \mathrm{kg}^{-1}\right)$ after three years of continuous barley under two soil tillage systems and three rates of nitrogen fertilization.

\begin{tabular}{|c|c|c|c|c|c|}
\hline & \multicolumn{5}{|c|}{ Layer } \\
\hline & $0-5 \mathrm{~cm}$ & $5-10 \mathrm{~cm}$ & $10-15 \mathrm{~cm}$ & $15-20 \mathrm{~cm}$ & $0-20 \mathrm{~cm}$ \\
\hline Tillage system & 0.001 & n.s. & 0.01 & n.s. & 0.01 \\
\hline NT & $43.6 \mathrm{~b}$ & 30.2 & $27.9 \mathrm{a}$ & 28.9 & $32.6 \mathrm{~b}$ \\
\hline $\mathrm{CT}$ & $30.8 \mathrm{a}$ & 30.0 & $29.6 \mathrm{~b}$ & 29.0 & $29.8 \mathrm{a}$ \\
\hline $\mathrm{N}$ fertilization & n.s. & n.s. & n.s. & n.s. & n.s. \\
\hline $\mathrm{N}_{0}$ & 37.0 & 29.7 & 28.7 & 29.2 & 31.1 \\
\hline $\mathrm{N}_{1}$ & 36.9 & 30.2 & 28.7 & 29.6 & 31.4 \\
\hline $\mathrm{N}_{2}$ & 37.6 & 30.5 & 28.7 & 28.0 & 31.2 \\
\hline Interaction & n.s. & n.s. & n.s. & n.s. & n.s. \\
\hline Average & 37.2 & 30.1 & 28.7 & 29.0 & 31.2 \\
\hline
\end{tabular}

n.s., not significant at the $\mathrm{P} \leq 0.05$ level; 0.01 and 0.001 , significantly different at $\mathrm{P} \leq 0.01$ and $\mathrm{P} \leq 0.001$ levels, respectively; within the same column, means followed by the same letter are not significantly different at the $\mathrm{P} \leq 0.05$ level, according to the LSD test. $\mathrm{NT}=$ no-tillage; $\mathrm{CT}=$ conventional tillage; $\mathrm{N}_{0}=0 \mathrm{~kg} \mathrm{~N} \mathrm{ha}^{-1} ; \mathrm{N}_{1}=50 \mathrm{~kg} \mathrm{~N} \mathrm{ha}^{-1} ; \mathrm{N}_{2}=90 \mathrm{~kg} \mathrm{~N} \mathrm{ha}^{-1}$.

upper layer, significantly higher than under CT (30.8). In the 10-15 cm layer there was a slight inversion between NT and CT, statistically significant $(\mathrm{P} \leq 0.01)$ and probably due to the stratification of the mouldboard ploughed residues in CT, relatively more intense in that layer. In any case, under NT the organic matter content of the soil in the $0-20 \mathrm{~cm}$ layer remained higher than under CT, even though the difference is limited (32.6 under NT vs $29.8 \mathrm{~g} \mathrm{~kg}^{-1}$ under CT). Thus, in this trial the contribution of conservative soil management to the balance of soil organic matter is evident after only three years, whereas several years or decades are usually necessary (Smith et al., 2000). Nevertheless, these findings agree with those of Campbell et al. (1999) for soils of the same textural class as the Cavacurta soil, i.e. silty loam. No effect of nitrogen fertilization and interaction was found. Table 4 presents the soil nitrogen content. The data clearly demonstrate the improvement in chemical fertility after three years of no-tillage. NT plots showed a higher nitrogen content than CT plots at a very high level of probability $(\mathrm{P} \leq 0.001)$ in both the upper $5 \mathrm{~cm}$ and the 20 $\mathrm{cm}$ layers. In the third layer, CT gave a significantly higher result than NT although the difference was very small (1.95 vs $\left.1.90 \mathrm{~g} \mathrm{~kg}^{-1}\right)$; the same pattern was shown by organic matter (Tab. 3). Fertilization had no effect on the nitrogen content. The available P (Tab. 5) followed the same pattern as the organic matter: in the upper $5 \mathrm{~cm}$ layer NT gave a very high Olsen $\mathrm{P}$ value, i.e. $6 \mathrm{mg} \mathrm{kg}^{-1}$ higher than for CT $(\mathrm{P} \leq 0.01)$. With

Table 4. Total nitrogen $\left(\mathrm{g} \mathrm{kg}^{-1}\right)$ after three years of continuous barley under two soil tillage systems and three rates of nitrogen fertilization.

\begin{tabular}{lccccc}
\hline & \multicolumn{5}{c}{ Layer } \\
\cline { 2 - 6 } & $0-5 \mathrm{~cm}$ & $5-10 \mathrm{~cm}$ & $10-15 \mathrm{~cm}$ & $15-20 \mathrm{~cm}$ & $0-20 \mathrm{~cm}$ \\
\hline Tillage system & 0.001 & n.s. & 0.01 & n.s. & 0.001 \\
$\mathrm{NT}$ & $2.64 \mathrm{~b}$ & 2.00 & $1.90 \mathrm{a}$ & 1.91 & $2.11 \mathrm{~b}$ \\
$\mathrm{CT}$ & $1.99 \mathrm{a}$ & 1.99 & $1.95 \mathrm{~b}$ & 1.96 & $1.97 \mathrm{a}$ \\
$\mathrm{N}$ fertilization & n.s. & n.s. & n.s. & n.s. & n.s. \\
$\mathrm{N}_{0}$ & 2.32 & 1.99 & 1.95 & 1.96 & 2.05 \\
$\mathrm{~N}_{1}$ & 2.28 & 2.01 & 1.93 & 1.95 & 2.04 \\
$\mathrm{~N}_{2}$ & 2.34 & 1.98 & 1.91 & 1.90 & 2.03 \\
Interaction & n.s. & n.s. & n.s. & 1.94 & n.s. \\
Average & 2.31 & 1.99 & 1.93 & 2.04 &
\end{tabular}

n.s., not significant at the $\mathrm{P} \leq 0.05$ level; 0.01 and 0.001 , significantly different at $\mathrm{P} \leq 0.01$ and $\mathrm{P} \leq 0.001$ levels, respectively; within the same column, means followed by the same letter are not significantly different at the $\mathrm{P} \leq 0.05$ level, according to the LSD test. $\mathrm{NT}=$ no-tillage; $\mathrm{CT}=$ conventional tillage $\mathrm{N}_{0}=0 \mathrm{~kg} \mathrm{~N} \mathrm{ha}{ }^{-1} ; \mathrm{N}_{1}=50 \mathrm{~kg} \mathrm{~N} \mathrm{ha}^{-1} ; \mathrm{N}_{2}=90 \mathrm{~kg} \mathrm{~N} \mathrm{ha}^{-1}$. 
Table 5. Available phosphorus ( $\mathrm{mg} \mathrm{kg}^{-1}$ ) after three years of continuous barley under two soil tillage systems and three rates of nitrogen fertilization.

\begin{tabular}{lccccc}
\hline & \multicolumn{5}{c}{ Layer } \\
\cline { 2 - 5 } & $0-5 \mathrm{~cm}$ & $5-10 \mathrm{~cm}$ & $10-15 \mathrm{~cm}$ & $15-20 \mathrm{~cm}$ & $0-20 \mathrm{~cm}$ \\
\hline Tillage system & 0.01 & n.s. & 0.05 & 0.001 & 0.01 \\
$\mathrm{NT}$ & $17.6 \mathrm{~b}$ & 9.4 & $10.2 \mathrm{~b}$ & $11.8 \mathrm{~b}$ & $12.3 \mathrm{~b}$ \\
$\mathrm{CT}$ & $11.6 \mathrm{a}$ & 9.2 & $8.5 \mathrm{a}$ & $8.8 \mathrm{a}$ & $9.3 \mathrm{a}$ \\
$\mathrm{N}$ fertilization & n.s. & n.s. & n.s. & n.s. & 10.4 \\
$\mathrm{~N}_{0}$ & 13.9 & 9.3 & 8.9 & 9.9 & 11.1 \\
$\mathrm{~N}_{1}$ & 15.3 & 9.5 & 9.7 & 10.8 & 10.9 \\
$\mathrm{~N}_{2}$ & 14.6 & 9.1 & 9.6 & n.s. & n.s. \\
Interaction & n.s. & n.s. & n.s. & 10.3 & 10.8 \\
Average & 14.6 & 9.3 & 9.4 & & \\
\hline
\end{tabular}

n.s., not significant at the $\mathrm{P} \leq 0.05$ level; $0.05,0.01$ and 0.001 significantly different at $\mathrm{P} \leq 0.05, \mathrm{P} \leq 0.01$ and $\mathrm{P} \leq 0.001$ levels, respectively; within the same column, means followed by the same letter are not significantly different at the $\mathrm{P} \leq 0.05$ level, according to the LSD test.

$\mathrm{NT}=$ no-tillage; $\mathrm{CT}=$ conventional tillage $\mathrm{N}_{0}=0 \mathrm{~kg} \mathrm{~N} \mathrm{ha}^{-1} ; \mathrm{N}_{1}=50 \mathrm{~kg} \mathrm{~N} \mathrm{ha}^{-1} ; \mathrm{N}_{2}=90 \mathrm{~kg} \mathrm{~N} \mathrm{ha}{ }^{-1}$.

the exception of the second layer, a higher value appeared in all the other layers, although reduced to about $3 \mathrm{mg} \mathrm{kg}^{-1}$. At the end of the three-year trial, the available $\mathrm{P}$ under $\mathrm{CT}$ fell within a medium-level range $\left(8-11 \mathrm{mg} \mathrm{kg}^{-1}\right)$, whereas under NT it was within a high-level range (12-15 $\mathrm{mg} \mathrm{kg}{ }^{-1}$ ), for which no $\mathrm{P}$ fertilizer is recommended for most crops (Rehm et al., 1994). The increase in soil organic matter under NT affected the availability of nutrients, particularly that of phosphorus. Nitrogen fertilization and interaction had no effects. Among the soil properties examined, CEC is the only one insensitive to the tillage system adopted (Tab. 6). Its slow reactivity to soil disturbances is well known, and in order to highlight some effects a longer trial period is generally required. On the contrary, the effect of nitrogen fertilization is significant, although the differences are too small $\left(1 \mathrm{cmol}^{+} \mathrm{kg}^{-1}\right.$ for the upper $5 \mathrm{~cm}$ layer and 0.6 for the $20 \mathrm{~cm}$ layer) to assume agronomic importance. No-till generally determines an increase in CEC parallel to the organic matter, whereas large amounts of nitrogen fertilizer have a tendency to reduce it (Russell et al., 2006). In this trial, the small CEC increases in the $\mathrm{N}_{2}$ subplots could be attributed to the organic matter increases in the upper $10 \mathrm{~cm}$ of the soil profile. Table 7 shows the percentage of water aggregate stability (WAS) related to the 0$20 \mathrm{~cm}$ layer and with the exception of $N_{1}$. This indicator is the most sensitive to soil management systems (Arshad and Coen, 1992), as already found in a parallel trial under maize

Table 6. Cation exchange capacity $\left(\mathrm{cmol}^{+} \mathrm{kg}^{-1}\right)$ after three years of continuous barley under two soil tillage systems and three rates of nitrogen fertilization.

\begin{tabular}{lccccc}
\hline & \multicolumn{5}{c}{ Layer } \\
\cline { 2 - 5 } & $0-5 \mathrm{~cm}$ & $5-10 \mathrm{~cm}$ & $10-15 \mathrm{~cm}$ & $15-20 \mathrm{~cm}$ & $0-20 \mathrm{~cm}$ \\
\hline Tillage system & n.s. & n.s. & n.s. & n.s. & n.s. \\
$\mathrm{NT}$ & 21.1 & 20.1 & 19.5 & 19.8 & 20.1 \\
$\mathrm{CT}$ & 20.1 & 20.0 & 20.0 & 19.8 & 20.0 \\
$\mathrm{~N}$ fertilization & 0.05 & n.s. & n.s. & 19.6 & 0.01 \\
$\mathrm{~N}_{0}$ & $20.4 \mathrm{a}$ & 19.9 & 19.3 & 19.7 & $19.8 \mathrm{a}$ \\
$\mathrm{N}_{1}$ & $20.2 \mathrm{a}$ & 19.8 & 19.8 & 20.2 & $19.9 \mathrm{a}$ \\
$\mathrm{N}_{2}$ & $21.2 \mathrm{~b}$ & 20.4 & 20.1 & n.s. & $20.5 \mathrm{~b}$ \\
Interaction & n.s. & n.s. & n.s. & 19.8 & n.s. \\
Average & 20.6 & 20.0 & 19.8 & 20.1 & \\
\hline
\end{tabular}

n.s., not significant at the $\mathrm{P} \leq 0.05$ level; 0.05 , and 0.01 , significantly different at $\mathrm{P} \leq 0.05$ and $\mathrm{P} \leq 0.01$ levels, respectively; within the same column, means followed by the same letter are not significantly different at the $\mathrm{P} \leq 0.05$ level, according to the LSD test. $\mathrm{NT}=$ no-tillage; $\mathrm{CT}=$ conventional tillage; $\mathrm{N}_{0}=0 \mathrm{~kg} \mathrm{~N}^{-1} ; \mathrm{N}_{1}=50 \mathrm{~kg} \mathrm{~N}^{-1} ; \mathrm{N}_{2}=90 \mathrm{~kg} \mathrm{~N} \mathrm{ha}^{-1}$. 
Table 7. Water aggregate stability (\%) after three years of continuous barley under two soil tillage systems and two rates of nitrogen fertilization.

\begin{tabular}{lc}
\hline & Layer \\
\cline { 2 - 2 } & $0-20 \mathrm{~cm}$ \\
\hline Tillage system & 0.01 \\
$\mathrm{NT}$ & $34.3 \mathrm{~b}$ \\
$\mathrm{CT}$ & $9.9 \mathrm{a}$ \\
$\mathrm{N}$ fertilization & n.s. \\
$\mathrm{N}_{0}$ & 20.6 \\
$\mathrm{~N}_{2}$ & 23.7 \\
Interaction & n.s. \\
Average & 22.1 \\
\hline
\end{tabular}

n.s., not significant at the $\mathrm{P} \leq 0.05$ level; 0.01 , significantly different at $\mathrm{P} \leq 0.01$ level; within the same column, means followed by the same letter are not significantly different at the $\mathrm{P} \leq 0.05$ level, according to the LSD test.

$\mathrm{NT}=$ no-tillage $; \mathrm{CT}=$ conventional tillage $; \mathrm{N}_{0}=0 \mathrm{~kg} \mathrm{~N} \mathrm{ha}^{-1} ; \mathrm{N}_{2}$ $=90 \mathrm{~kg} \mathrm{~N} \mathrm{ha}^{-1}$.

(Tabaglio et al., 2008). Under NT, the WAS is $246 \%$ higher compared with CT $(\mathrm{P} \leq 0.01)$, where the stable aggregates are only $9.9 \%$. If the aim of no-tillage is a better soil aggregate stability (Paris, 1989), this result appears to be achieved after a three-year period in the pedoclimatic conditions of this trial. The effect is evident not only in the upper $5-10 \mathrm{~cm}$ layer but also up to a depth of $20 \mathrm{~cm}$, with more positive agronomic consequences. Nitrogen fertilization and interaction had no effect. These findings are exciting, because the indicators used reacted quickly to soil management changes. They are mainly due to crop residues, which represent the most important contribution to the turnover of organic $\mathrm{C}$ in the soil, and also to more abundant root residues. However, the favourable pedological conditions of the experimental site should be considered; in soils with a texture less suitable to no-till the improvement will probably be slower and weaker.

As regards the microarthropod community, different treatments do not lead to significant differences (Fig. 1). The value of the QBS-ar index was between 90 and 126, a typical range for soil under wheat and barley (unpublished data). The observed community of microarthropods highlights the fairly good biological quality of the soil for all four treatments and this is presumably due to the fact that barley, in contrast with other crops such as maize which have a

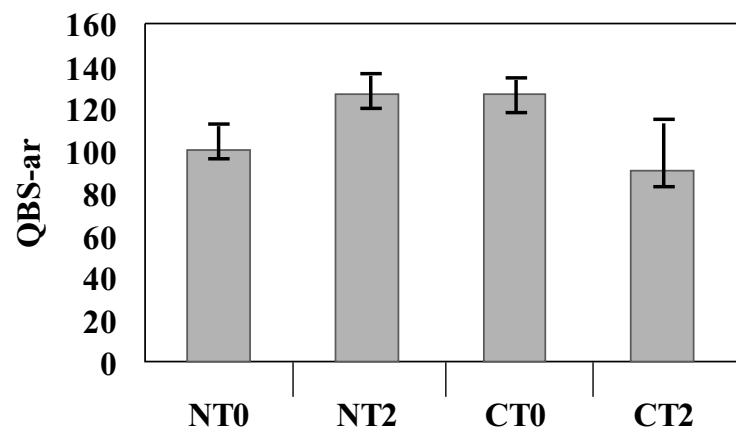

Figure 1. QBS-ar values and standard deviation after three years of trial. The QBS-ar index is based on microarthropod groups present in a soil sample and each "microarthropod-type" found receives a score from 1 to 20 (Eco-Morphological Index, EMI), according to its adaptation to the soil environment. The QBS-ar index sums up these scores. The treatments did not show significant differences. NT0 $=$ NT at $0 \mathrm{~kg} \mathrm{~N} \mathrm{ha}^{-1} ; \mathrm{NT} 2=\mathrm{NT}$ at $90 \mathrm{~kg} \mathrm{~N}$ ha $^{-1} ;$ CT0 $=$ CT at $0 \mathrm{~kg} \mathrm{~N} \mathrm{ha}^{-1}$; CT2 $=$ CT at $90 \mathrm{~kg} \mathrm{~N} \mathrm{ha}^{-1}$.

higher impact on the soil, maintains conditions of the edaphic environment suitable for the survival of edaphic microarthropods.

\section{Conclusions}

The agronomic advantages of no-tillage were thus confirmed after a short trial period. Soil organic matter, total nitrogen, available phosphorus and, especially, water aggregate stability are significantly increased under no-tillage compared with conventional tillage. The increase in WAS is the most important result of this research, because it represents the real agronomic achievement at the end of the transition process towards a new equilibrium of the soil system. For NT plots the value was $246 \%$ higher than for CT plots. The physical and chemical properties studied, with the exception of CEC, were revealed as being sensitive and reliable indicators of soil health. In relation to the QBSar index, different treatments do not result in significant differences. $\mathrm{N}$ fertilization had no effects on the studied indicators, with the exception of CEC, which was significantly higher in the $\mathrm{N}_{2}$ subplots for a very small difference.

In a context requiring agriculture to adopt sustainable practices, with UE agricultural policies forcing farmers to adopt reduced environmental impact systems in order to obtain income support, it is necessary to find the most 
reliable indices possible for verifying the results obtained in soil quality and health.

\section{References}

Adl S.M., Coleman D.C., Read F. 2006. Slow recovery of soil biodiversity in sandy loam soils of Georgia after 25 years of no-tillage management. Agric. Ecosyst. Environ., 114:323-334.

Angas P., Lampurlanes J., Cantero-Martinez C. 2006. Tillage and $\mathrm{N}$ fertilization: effects on $\mathrm{N}$ dynamics and barley yield under semiarid Mediterranean conditions. Soil Till. Res., 87:59-71.

Arshad M.A., Coen G.M. 1992. Characterization of soil quality: physical and chemical criteria. Am. J. Alter. Agric., 7:25-31.

Baker C.J., Saxton K.E. (eds.) 2006. No-tillage seeding in conservation agriculture ( $2^{\text {nd }}$ ed.). FAO \& CABI Publishing, Wallingford, Oxon, UK.

Bartolini R. (ed.) 1989. Coltivare conservando. Edizioni Agricole, Bologna, Italy.

Caliandro A., Rizzo V., Mosca G., Stefanelli G., Manzini S., Bonari E., Mazzoncini M., Bonciarelli F., Archetti R., De Giorgio D., Basso F., Postiglione L., Rubino P., Lo Cascio B., Venezia G. 1992. Risultati sperimentali ottenuti su cereali a paglia con diverse tecniche di lavorazione al terreno. Riv. Agron., 26:215-222.

Campbell C.A., Biederbeck V.O., McConkey B.G., Curtin D., Zentner R.P. 1999. Soil quality: effect of tillage and fallow frequency. Soil organic matter quality as influenced by tillage and fallow frequency in a silt loam in Southern Saskatchewan. Soil Biol. Biochem., 31:1-7.

Doran J.W., Parkin T.B. 1994. Defining and assessing soil quality. In: Doran J.W., Coleman D.C., Bezdicek D.F., Stewart B.A. (eds.): Defining soil quality for a sustainable environment, 3-21. SSSA Spec. Publ. 35, SSSA, Madison, WI, USA.

Halvorson A.D., Reule C.A. 2007. Irrigated, no-till corn and barley response to nitrogen in northern Colorado. Agron. J., 99:1521-1529.

Kemper W.D. 1965. Aggregate stability. In: Black C.A. (ed.): Methods of soil analysis, Part 1,511-519. Agronomy, Monograph no. 9, ASA, Madison, WI, USA.

Kjeldahl J. 1883. Neue Methode zur Bestimmung des Stickstoffs in organischen Körpern. Z. Anal. Chem., 22:366-382.

Landi L., Renella G., Nannipieri P. 2000. Indicatori chimici della qualità del suolo: il ruolo della sostanza organica. Memorie di scienze fisiche e naturali, Rendiconti Accademia Nazionale delle Scienze detta dei XL, 24:239-248.

Larson W.E., Pierce F.J. 1991. Conservation and enhancement of soil quality. In: Int. Workshop on Evaluation for sustainable land management in the developing world, Chiang Ray, Thailand, 15-21 Sept.,
Int. Board for Soil Res. and Manage., Bangkok, Thailand, 175-203.

Malhi S.S., Lemke R. 2007. Tillage, crop residue and N fertilizer effects on crop yield, nutrient uptake, soil quality and nitrous oxide gas emissions in a second 4-yr rotation cycle. Soil Till. Res., 96:269-283.

Malquori A., Cecconi S. 1962. Determinazione seriale dell'indice di struttura del terreno. Agrochimica, 6:199-204.

Olsen S.R., Sommers L.E. 1982. Phosphorus. In: Page A.L., Miller R.H., Keeney D.R. (eds.): Methods of soil analysis, Part 2, 403-430. Agronomy, Monograph no. 9, ASA-SSSA, Madison, WI, USA.

Paris P. 1989. L'uso del terreno al di là dell'aratura. In: Bartolini R. (ed.): Coltivare conservando, 19-26. Edizioni Agricole, Bologna, Italy.

Parisi V. 2001. La qualità biologica del suolo. Un metodo basato sui microartropodi. Acta Naturalia de «L'Ateneo Parmense», 37:105-114.

Parisi V., Menta C., Gardi C., Jacomini C., Mozzanica E. 2005. Microarthropod communities as a tool to assess soil quality and biodiversity: a new approach in Italy. Agric. Ecosyst. Environ., 105:323-333.

Phillips R.E., Phillips S.H. (eds.) 1984. No-tillage agriculture. Principles and practices. Van Nostrand Reinhold Company, New York, USA.

Pisante M. (ed.) 2007. Agricoltura blu - La via italiana dell'agricoltura conservativa. Edagricole, Bologna, Italy.

Rajendra Prasad, Power J.F. 1991. Crop residue management. Adv. Soil Sci., 15:205-251.

Rehm G.W., Schmitt M., Munter R. 1994. Fertilizer recommendations for agronomic crops in Minnesota. Minnesota Ext. Serv. BU-6240-E, Univ. of Minnesota, St. Paul, USA.

Reicosky D.C., Saxton K.E. 2007. The benefits of notillage. In: Baker C.J., Saxton K.E. (eds.) No-tillage seeding in conservation agriculture, 11-20. FAO \& CABI, Wallingford, Oxfordshire, UK.

Russell A.E., Laird D.A., Mallarino A.P. 2006. Nitrogen fertilization and cropping system impacts on soil quality in Midwestern Mollisols. Soil Sci. Soc. Am. J., 70:249-255.

Sartori L., Peruzzi A. 1994. The evolution of no-tillage in Italy: a review of the scientific literature. In: F. Tebrügge (ed.): Experience with the applicability of no-tillage crop production in the West-European Countries. Concerted Action ( $\mathrm{N}^{\circ}$ AIR 3 - CT 931464). Proceedings of the EC-Workshop - I Giessen, 27-28 June 1994, Wissenschaftlicher Fachverlag, Giessen, Germany, 119-129.

Smith O.H., Petersen G.W., Needelman B.A. 2000. Environmental indicators of agroecosystems. Adv. Agron., 69:75-97.

Soil Taxonomy 1992. Soil Survey Staff. Keys of soil taxonomy. SMSS Technical Monograph n. 19, Virginia Polytechnic Inst. and State University, USA. 
Sprague M.A., Triplett G.B. (eds.) 1986. No-tillage and surface tillage agriculture. The tillage revolution. John Wiley \& Sons, New York, USA.

Tabaglio V., Gavazzi C., Beone G.M. 2008. Soil quality indicators as influenced by no-tillage, conventional tillage and nitrogen fertilization after 3 years of continuous maize in the Po Valley. Agrochimica, in press.

Toderi G., Bonari E. 1986. Lavorazioni del terreno: aspetti agronomici. II. Lavorazioni e pianta coltivata. Riv. Agron., 20:106-133.

Triplett G.B., Jr., Dick W.A. 2008. No-tillage crop production: a revolution in agriculture! Agron. J., 100:S153-S165.
Unger P.W., McCalla T.M. 1980. Conservation tillage systems. Adv. Agron., 33:1-58.

van Straalen N.M. 1998. Evaluation of bioindicator systems derived from soil arthropod communities. Appl. Soil Ecol., 9:429-437.

Walkley A., Black I.A. 1934. An examination of Degtjareff method for determining soil organic matter and a proposed modification of the chromic acid titration method. Soil Sci., 37:29-38.

Wild A. (ed.) 1988. Russell's soil conditions and plant growth (11 ${ }^{\text {th }}$ ed.). Longman Scientific \& Technical, Harlow, Essex, England. 